\title{
Nutritional Quality of Herbaceous Vegetation in a Phryganic Mediterranean Ecosystem During the Grazing Period
}

\author{
Christos N. ROUKOS ${ }^{1 *}$, Apostolos P. KYRIAZOPOULOS ${ }^{2}$, \\ Eleni M. ABRAHAM ${ }^{3}$, Zoi M. PARISSI ${ }^{3}$, Maria KARATASSIOU ${ }^{4}$ \\ ${ }^{I}$ Ministry of Rural Development and Food, Regional Department of Epirus \& Western Macedonia, \\ 45445 Ioannina, Greece; roukxris@gmail.com (*corresponding author) \\ ${ }^{2}$ Democritus University of Thrace, Department of Forestry and Management of the Environment and Natural Resources, 193 Pantazidou str., \\ 68200 Orestiada, Greece; apkyriaz@fmenr.duth.gr \\ ${ }^{3}$ Aristotle University of Thessaloniki, Department of Forestry and Natural Environment, Laboratory of Range Science (236), \\ 54124 Thessaloniki,Greece; eabraham@for.auth.gr \\ ${ }^{4}$ Aristotle University of Thessaloniki, Department of Forestry and Natural Environment, Laboratory of Rangeland Ecology (286), \\ 54124 Thessaloniki, Greece; karatass@for.auth.gr
}

\begin{abstract}
Grazing is an economically and environmentally valuable activity in phryganic Mediterranean ecosystems. The herbaceous vegetation of these ecosystems provides an essential feed source for grazing ruminants. Despite the extension and economic importance of phryganic ecosystems in Mediterranean Basin there has been relatively little scientific focus on nutritional quality of their herbaceous vegetation. The nutritional quality of herbaceous vegetation in a phryganic ecosystem was assessed for two consecutive years during the grazing period (March to July). Herbage samples were analysed for chemical composition, metabolizable energy, in vitro dry matter digestibility, in vitro neutral detergent fiber digestibility and mineral content $(\mathrm{Ca}, \mathrm{P}$, $\mathrm{K}, \mathrm{Mg}$ ) at monthly basis. According to the results time of harvest significantly affected crude protein, neutral detergent fiber, acid detergent fiber, lignin and the content of minerals (i.e. Ca, P, Mg, K). Mean monthly temperature found to have a great negative impact on nutritional quality. During the grazing period, the nutritional quality of herbage vegetation was strongly correlated with growing degree days. Over a threshold of about 700 growing degree days the nutritional quality of herbage dramatically decreased. Overall the current study provides crucial information for the nutritional dynamics of the herbage vegetation of the phryganic Mediterranean ecosystems that can be towards developing an efficient grazing strategy.
\end{abstract}

Keywords: chemical composition, growing degree days, digestibility, phrygana, minerals

Abbreviations: ADF, acid detergent fiber; CP, crude protein; GDD, growing degree days; IVDMD, in vitro dry matter digestibility; IVNDFD, in vitro neutral detergent fiber digestibility; ME, metabolizable energy; NDF, neutral detergent fiber

\section{Introduction}

Phrygana, known as 'tomillares' in Spain, 'garrigue' in France, 'gariga' in Italy and 'coastal sage' in California, are open, dwarf shrub communities widespread in dry areas. It is a characteristic vegetation type of the Mediterranean ecosystems that usually grows on dry, rocky and friable soils (Debazac and Mavrommatis, 1969; Kyparissis et al., 1997; Cherubini et al., 2003). Phrygana have adopted a peculiar strategy to withstand the summer droughtstress of the Mediterranean climate by replacing the large winter leaves by the much smaller summer ones in order to conserve water (Kypasissis and Manetas, 1993; Kyparissis et al., 1997).
Phlomis fruticosa L. (Jerusalem sage), a semi-deciduous drought-hardy and flammable dwarf shrub of about $150 \mathrm{~cm}$ tall (Greuter et al., 1986), is the dominant species of phryganic ecosystems in lower and middle altitudes of Western Greece. In these ecosystems, a rich herbaceous flora usually occurs providing a valuable feed source for extensive livestock farming systems in marginal areas that are unsuitable for agriculture use (Kandrelis, 2000).

However, Phlomis fruticosa is an unpalatable species to ruminant livestock. Therefore, its encroachment results in a significant reduction of grazable species and in turn decreases grazing capacity (Roukos et al., 2008). On the other hand, there is a widespread concern about the negative impact of livestock 
150

overgrazing on phryganic ecosystems. Negative impacts of overgrazing in such ecosystems are dramatically increased when combined with burning (Papanastasis et al., 2002) and possibly lead to desertification (Geist and Lambin, 2004).

Several factors affect the nutritional quality of herbaceous vegetation which, in turn, directly influences the pasture ability to sustain animal production (Holechek et al., 2010). Climatic conditions, botanical composition, soil properties and topography may differentiate the nutritional quality of herbage, which needs to be precisely estimated in order to determine a proper management plan (Vazquez-de-Aldana et al., 2000; Ayan et al., 2006; Bovolenta et al., 2008; Ramirez et al., 2009; Holechek et al., 2010; Mountousis et al., 2011; Roukos et al., 2011a).

Variations in herbage nutritional quality are reflected in animal performance which is related closely to dry matter intake and nutrient digestibility (Coleman and Moore, 2003). Consequently, the risk of metabolic disorders can be increased when livestock graze low quality herbage. For example, grass tetany is related to the mineral composition of the feed (Jefferson et al., 2001) and occurs primarily in lactating cows, less frequently in lactating sheep and occasionally in lactating goats (Caple and West, 1992; Pugh and Baird, 2012).

Most of the studies on the nutritional quality of herbaceous vegetation in the Mediterranean Basin have been carried out in grasslands and shrublands. On the contrary, few such studies have been conducted in phryganic ecosystems which are characterized by harsher soil, special climatic and vegetation characteristics compared to the grasslands (Montalvo et al., 1991; Roukos et al., 2011b).

Greece is predominantly a mountainous country with phryganic ecosystems growing from the sea level up to the subalpine region in northern areas of the country (Egli, 1991). However, apart from studies on assemblages of the phryganic vegetation by Papanastasis et al. (2002), Bergmeier (1997) and Bergmeier \& Matthäs (1996) and management (Kandrelis, 1995; Kandrelis, 2000; Roukos et al., 2008) no detailed research has been carried out on the effects of climatic condition on the nutritional quality of herbage yield at the phryganic ecosystems.

The aim of this study was to determine the nutritional quality characteristics of the above ground herbage biomass of a phryganic ecosystem in relation to its monthly development during the grazing period.

\section{Materials and Methods}

\section{Study area and climate}

This investigation was conducted on the foothills of Xirovouni Mountain $\left(20.942940^{\circ}\right.$ longitude, $39.370576^{\circ}$ latitude) located in northwestern Greece. The study area is a typical phryganic ecosystem of western Greece extended between shrublands and grasslands. In this intricate spatial mosaic are extended 3,150 hectares of phrygana vegetation which is be grazing of approximately 1,000 head of cattle and more than 30,000 head of sheep under extensive management. These figures are based on a live weight of $50 \mathrm{~kg}$ for sheep and a $200 \mathrm{~kg}$ for free-ranging beef cattle (with average daily growth of less than $0.5 \mathrm{~kg}$ ).

Long-term climatic records for the study area were provided by the Hellenic National Meteorological Service (HNMS, 2009). These records indicated a typical Mediterranean climate, characterised as Csa according to Köppen (Hatzianastassiou $e t$ al., 2008). The average air temperatures in January and July was $8.7^{\circ} \mathrm{C}$ and $26.5^{\circ} \mathrm{C}$, respectively, (considering data from 19761997) while the mean annual rainfall $1,084.6 \mathrm{~mm}$. Soils are calcaceous with $\mathrm{pH}$ values ranging between 7.1 and 7.8, containing rather insufficient availability of N, P and $\mathrm{K}$ (Roukos et al., 2011b). Geologically, the plain belongs to the Ionian geotectonic zone. The basic substrates are dolomites, Viglas limestones and flisch.

\section{Samplingmethods and experimental data collection}

Field data were collected during two consecutive growing seasons within 10 experimental plots of $5 \mathrm{~m} \times 5 \mathrm{~m}$ each with western-southwestern aspects. The experimental plots were established during January and slightly different in altitude above sea level which ranged from $125 \mathrm{~m}$ to $476 \mathrm{~m}$. Herbaceous vegetation was dominated by five grasses (Avena sterilis, Dactylis glomerata, Melica ciliata, Piptatherum miliaceum, Stipa bromoides), eight legumes (Anthylis hermaniae, Medicago falcata, Medicago lupulina, Medicago minima, Trifolium arvense, Trifolium campestre, Trifolium purpureum, Trifolium subterraneum) and five forbs (Daucus guttatus, Plantago bellardii, Scabiosa sp., Scolymus hispanicus, Stachys germanica). Handclipped samples were collected for five monthly intervals from the beginning of the growing period (early March) until the senescence of plant species (early July). Sampling was performed by cutting the herbaceous biomass at ground level at approximately $5 \mathrm{~cm}$ within eight randomly selected quadrats of $0.25 \mathrm{~m}^{2}$ inside each experimental plot at monthly basis. Samples were immediately placed into individual paper bags, transported to the laboratory and dried for $48 \mathrm{~h}$ in a $55^{\circ} \mathrm{C}$ oven, ground with a Kinematica mill (model Polymix PX-MFC 90D), passed through a $1 \mathrm{~mm}$ sieve and stored at $4^{\circ} \mathrm{C}$ until further analysis.

Climatic data during the experiment were collected from two automatic weather stations (Onset $\mathrm{HOBO}$ weather station) installed in the experimental area (Fig. 1). For each sample per month, precipitation and temperature data were associated with the nearest weather station. Then, accumulated growing degree days (GDD) were calculated for each month of harvest using the mean-minus-base method (Pruess, 1983; Frank and Hofmann, 1989; Frank et al., 1998) using the formula: GDD = $[($ maximum daily temperature + minimum daily temperature)/2] - base temperature.

The basal growth temperature was set at $10^{\circ} \mathrm{C}$ as it reflects the essential temperature for the initiate development of warm season grasses (Frank, 1996), although lower value has been reported from Unruh et al. (1996). Also, a lower limit of $10^{\circ} \mathrm{C}$ was set for the minimum temperature. Growing day degrees were summed from 1 January of each year according to Hendrickson et al. (1998).

\section{Analyticalmethods}

Monthly herbage samples were analyzed for dry matter (DM), ash, ether extract and crude protein (CP) (methods $930.15,942.05,920.39$ and 976.05, respectively, of the A.O.A.C., 2000).

Neutral detergent fiber (NDF), acid detergent fiber (ADF) and sulfuric acid lignin (lignin(sa)) were determined using an ANKOM Fiber Analyzer (ANKOM Technology, Macedon, NY, USA) according to procedure describes by Van Soest et al. (1991) and modified by Vogel et al. (1999) for the ANKOM 


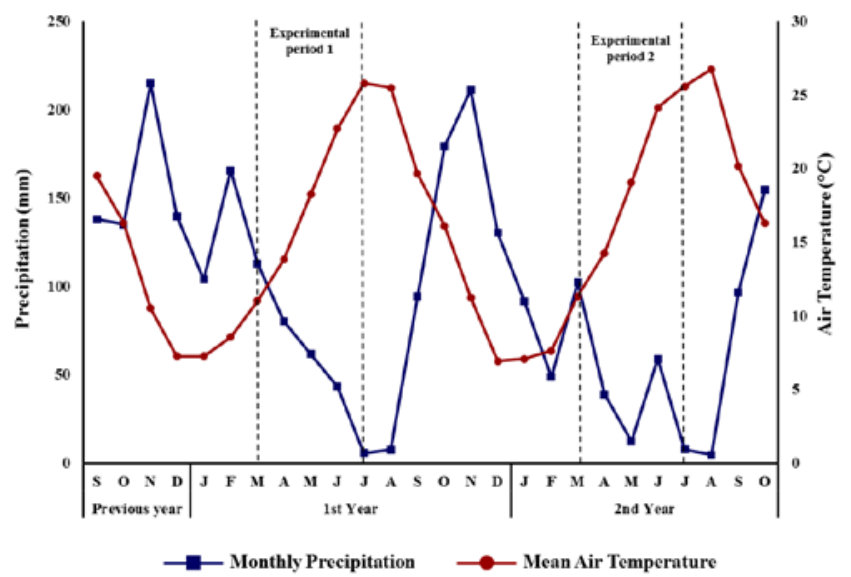

Fig. 1. Climatic diagram of the study area during the two years experimental period

system. For NDF analysis, samples were treated with heat-stable amylase (A3306, Sigma-Aldrich, St. Louis, MO, USA) without sodium sulfite in the neutral detergent (ND). NDF and ADF are expressed without residual ash. In vitro dry matter (DM) digestibility (IVDMD) was measured according to Vogel et al. (1999) using an ANKOM DaisyII incubator (ANKOM Technology). Rumen fluid was obtained from eight nonlactating Holstein cows fed according to their nutritional requirements. The gross energy of each herbage sample was measured using an adiabatic bomb calorimeter (model IKA C5000, IKA Works Inc., Wilmington, NC, USA). Postdigestion analyses were completed on the undigested residue to determine the NDF concentration using the above-described methods, and on the gross energy of the residue using a bomb calorimeter. In vitro neutral detergent fiber (NDF) digestibility (IVNDFD) was calculated according to Hall and Mertens (2008), as: IVNDFD $(\mathrm{g} / \mathrm{kg} \mathrm{NDF})=(1-$ [post-digestion dry weight following ND wash/pre-digestion dry weight of NDF]). Additionally, digestible energy was determined using the following formula: $\mathrm{DE}(\mathrm{MJ} / \mathrm{kg} \mathrm{DM})=($ pre-digestion gross energy - [gross energy in residue $\times(1-$ IVDMD $)])$. Metabolisable energy (ME) was calculated using an equation adapted from NRC (2006): $\mathrm{ME}=\mathrm{DE} \times 0.82$

Concentrations of $\mathrm{K}, \mathrm{Ca}, \mathrm{Mg}$ and $\mathrm{P}$ in the herbage samples were assessed in triplicate by oxidizing each subsample with a 2:1 nitric/perchloric acid mixture. In separate aliquots, $\mathrm{Ca}$ and $\mathrm{K}$ were determined by flame photometry, $\mathrm{P}$ by spectrophotometric methods (Khalil and Manan, 1990) and $\mathrm{Mg}$ by atomic absorption spectrophotometry (AOAC, 1999; method 968.08) (model PERKIN ELMER/AA800, PerkinElmer Inc., San Jose, CA, USA).

The risk of grass tetany was evaluated using an equation adapted from Kemp and Hart (1957) as: grass tetany index $(\mathrm{GTI})=\mathrm{K}^{+} /\left(\mathrm{Ca}^{2+}+\mathrm{Mg}^{2+}\right)$, with each element expressed in $\mathrm{mmolc} / \mathrm{kgDM}(\mathrm{mg} / \mathrm{kg} \mathrm{DM} \times 1000 \times$ valence/atomic weight $)$.

\section{Statistical analyses}

One-way analysis of variance (ANOVA) was carried out to determine the effect of time of harvest on chemical composition, mineral contents and nutrient digestibility of herbage samples. The normality of the distribution was determined through the Shapiro-Wilk's test. Since the samples had a normal distribution, the one-way ANOVA with LSD's post hoc test was used.
Differences were considered statistically significant at the $\mathrm{P}<$ 0.05 level. In addition, the Pearson's correlation was employed to examine relationships between nutritive quality variables, climatic variables and altitude (Steel and Torrie, 1980). The relationship between growing degree days and nutritive quality variables were tested using regression analysis. All analyses were conducted using IBM SPSS Statistics v. 21.0.0 (New York, USA) software.

\section{Results and Discussion}

\section{$C P$ and cell wall contents}

Month of harvest significantly $(\mathrm{P}<0.001)$ influenced the $\mathrm{CP}$, ether extract and cell wall contents of herbage (Table 1) during the grazing period. The $\mathrm{CP}$ and ash content had a progressive decrease throughout the grazing period, while cell wall contents increased dramatically from March to July. Correlation analysis revealed that $\mathrm{CP}$ and ash contents are negatively $(\mathrm{P}<0.01)$ associated with mean monthly air temperature $(\mathrm{r}=-0.940$ and $\mathrm{r}=-0.667$, respectively). On the contrary, cell wall contents are positively correlated with mean monthly air temperature (Table 2).

The $\mathrm{CP}$ content is a reliable measure of herbage nutritional quality (Ganskoop and Bohnert, 2001) as affects dry matter intake through the microbial activity in rumen (Merkel et al., 1999). High dietary CP levels are positively associated with the degradation of protein in the rumen and have been shown to decrease the efficiency of nitrogen utilization for milk production (Broderick, 2003; Hristov et al., 2004).

The adequate $\mathrm{CP}$ requirement threshold for maintenance of livestock range from $82 \mathrm{~g} / \mathrm{kg}$ for growing beef cattle (with a live weight of $300 \mathrm{~kg}$ and an average daily gain of $0.22 \mathrm{~kg}$ ) to 95 $\mathrm{g} / \mathrm{kg}$ for sheep (with a live weight of $50 \mathrm{~kg}$ ) (NRC, 1985; 1996). Thus, except July, the CP levels in herbage were sufficient to meet the daily requirements of sheep and freeranging beef cattle and can be considered to be of high nutritional quality for grazing livestock.

The $\mathrm{CP}$ content of forage reflects the climatic conditions during plant growth and development (Holechek et al., 2010) and is markedly decreased with forage plant maturity (PerezCorona et al., 1998; Ramirez et al., 2004; Mountousis et al., 2008; Roukos et al., 2010; Mountousis et al., 2011; Acar et al., 2016). Additionally, ether extract tended to increase from March to May and decreased afterwards till July. This pattern is in agreement with SCA (1990), and Mountousis et al. (2008).

The proportion of NDF, ADF and lignin considerably increased in herbage throughout the grazing period as it is associated with the plant maturation, a result also found by Perez-Corona et al. (1998), Roukos et al. (2010), Mountousis et al. (2011) and Acar et al. (2016).

Moreover, the voluntary dry matter intake is limited by NDF concentration higher than $600 \mathrm{~g} / \mathrm{kg}$ due to rumen fill (Mertens, 1994; Allen, 1996). The NDF content of herbage exceed the above mentioned threshold only on July, when the highest $\mathrm{ADF}$ and lignin contents during the grazing season were observed. However, during June NDF content was close to the above threshold and can be regarded as high level.

The highest lignin content was observed at the last two months of the grazing period (June and July), probably as a consequence of the significant increase of air temperature during this period of the year. 
Table 1.Effect of harvest date on crude protein (CP), ether extract (EE) and cell wall concentrations of herbaceous vegetation during grazing period

\begin{tabular}{|c|c|c|c|c|c|c|c|}
\hline Parameter & March & April & May & June & July & SEM & Sig. \\
\hline $\mathrm{CP}(\mathrm{g} / \mathrm{kg} \mathrm{DM})$ & $206 a$ & $199 \mathrm{a}$ & $155 b$ & $107 \mathrm{c}$ & $73 \mathrm{~d}$ & 3.8 & $* * *$ \\
\hline $\mathrm{EE}(\mathrm{g} / \mathrm{kg} \mathrm{DM})$ & $15 \mathrm{ab}$ & $15 \mathrm{a}$ & $17 \mathrm{a}$ & $16 \mathrm{a}$ & $14 \mathrm{~b}$ & 0.6 & * \\
\hline NDF (g/kg DM) & $334 \mathrm{e}$ & $409 \mathrm{~d}$ & $561 \mathrm{c}$ & $591 \mathrm{~b}$ & 641a & 13.4 & *** \\
\hline $\mathrm{ADF}(\mathrm{g} / \mathrm{kg} \mathrm{DM})$ & $236 \mathrm{e}$ & $292 \mathrm{~d}$ & $333 c$ & $386 \mathrm{~b}$ & $435 a$ & 10.2 & *** \\
\hline $\operatorname{Lignin}(\mathrm{sa})(\mathrm{g} / \mathrm{kg} \mathrm{DM})$ & $33 \mathrm{~d}$ & $44 c$ & $44 c$ & $64 \mathrm{~b}$ & $71 \mathrm{a}$ & 2.2 & *** \\
\hline
\end{tabular}

Within a row, means with different letters differ at $\mathrm{P}<0.05$.

SEM = standard error of the mean; Sig = significant level

${ }^{*} \mathrm{P}<0.05 ;{ }^{* *} \mathrm{P}<0.01 ;{ }^{* * *} \mathrm{P}<0.001 ; \mathrm{NS}=$ not significant

Table 2.Correlation coefficients between chemical composition parameters of herbaceous vegetation and climatic parameters during the grazing period

\begin{tabular}{|c|c|c|}
\hline Parameter & Mean montly air temperature & Monthly Precipitation \\
\hline CP (g.kd DM) & $-0.940^{* \prime}$ & $0.634^{* *}$ \\
\hline $\mathrm{EE}(\mathrm{g} / \mathrm{kg} \mathrm{DM})$ & 0.086 & -0.152 \\
\hline $\operatorname{NDF}(g / k g D M)$ & $0.863^{\prime \prime}$ & $-0.676^{* *}$ \\
\hline $\mathrm{ADF}(\mathrm{g} / \mathrm{kg} \mathrm{DM})$ & $0.916^{* *}$ & $-0.624^{* *}$ \\
\hline Lignin (g/kg DM) & $0.882^{*}$ & $-0.539^{* *}$ \\
\hline Ash(g/kg DM) & $-0.657^{* *}$ & $0.448^{* *}$ \\
\hline $\mathrm{ME}(\mathrm{MJ} / \mathrm{kg} \mathrm{DM})$ & $-0.596^{*}$ & $0.554^{* \prime}$ \\
\hline IVDMD & $-0.887^{* *}$ & $0.510^{* *}$ \\
\hline IVNDFD & $-0.896^{\prime \prime}$ & $0.534^{*}$ \\
\hline$P(g / k g ~ D M)$ & $-0.440^{* *}$ & 0.182 \\
\hline $\mathrm{K}(\mathrm{g} / \mathrm{kg} \mathrm{DM})$ & $-0.476^{* *}$ & $0.307^{* \prime}$ \\
\hline $\mathrm{Ca}(\mathrm{g} / \mathrm{kg} \mathrm{DM})$ & -0.171 & 0.006 \\
\hline $\mathrm{Mg}(\mathrm{g} / \mathrm{kg} \mathrm{DM})$ & $-0.294^{* *}$ & $0.223^{*}$ \\
\hline GrassTetanyIndex & -0.149 & 0.193 \\
\hline
\end{tabular}

\section{Mineral composition and grass tetany index}

In general, herbage had $\mathrm{Ca}, \mathrm{P}, \mathrm{K}, \mathrm{Mg}$ and ash contents that were significantly $(\mathrm{P}<0.05)$ different between time of harvest (Table 3). On the other hand the GT index did not significantly differ among the harvest dates. Mineral and ash concentrations diminished from the second month of harvest (April) onwards showing their lowest values in July. Similar trends in mineral and ash concentration were found by Mountousis et al. (2006; 2008) and can be caused by the increased air temperature (Bertrand et al., 2008) and its negative impact on plant mineral intake from the soil (Wang $e t$ al., 2006). Also, the reduction in mineral and ash content during plant growth has been attributed to the increased dry matter yield due to dilution of minerals in plant tissue (Pelletier etal.,2006).

Minerals are essential to livestock for both growth and milk production (Suttle, 2010). In general, mineral content in herbage depends chiefly on its botanical composition, soil and climatic conditions during growing season (Holechek et al., 2010; Suttle, 2010; Roukos et al., 2011a).

Herbaceous vegetation is generally satisfactory sources of $\mathrm{Ca}$ for grazing livestock, particularly when they contain leguminous species, thus calcium deprivation rarely affects grazing livestock (Suttle, 2010). Ewes with a $50 \mathrm{~kg}$ live weight and beef cattle with a $200 \mathrm{~kg}$ live weight require about $2 \mathrm{~g}$ of $\mathrm{Ca} / \mathrm{kg}$ DM (NRC, 1985) and $1.2 \mathrm{~g}$ of $\mathrm{Ca} / \mathrm{kg}$ DM (NRC, 1996), respectively. It seems that herbage during the grazing period had sufficient Ca levels to meet these requirements.

Phosphorus maintenance requirements for beef cattle and

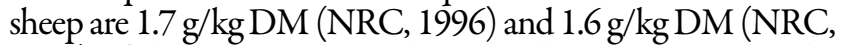
1985) of their diet, respectively. According to the results, the herbage had sufficient $\mathrm{P}$ levels to meet the maintenance requirements of grazing livestock. Roukos et al. (2011a) reported higher values of $\mathrm{Ca}$ and $\mathrm{P}$ in herbage collected from grasslands in adjacent area. On the contrary, Ganskoop and
Bohnert (2001) and Ramirez et al. (2009) found inadequate levels of $\mathrm{P}$ in forages to meet maintenance requirements of sheep and cattle in grasslands of arid environments of USA and Mexico, respectively.

Potassium is most associated with nerve and muscle excitability as well as water and acid-base balance. This element must be evaluated in relation to $\mathrm{Mg}$ as high $\mathrm{K}$ levels in diet may cause $\mathrm{Mg}$ deficiency due to interactions between these minerals in absorbance (Suttle, 2010). All herbage samples during the grazing period had adequate $\mathrm{K}$ levels to meet the optimum maintenance requirements for beef cattle $(6 \mathrm{~g} / \mathrm{kg}$ DM; NRC, $1996)$ and sheep ( $5 \mathrm{~g} / \mathrm{kg} \mathrm{DM}$; NRC, 1985). Herbage biomass with sufficient $\mathrm{K}$ content to meet the maintenance requirements for beef cattle and sheep was also found by Ganskoop and Bohnert (2001), Ramirez et al. (2009) in grasslands of northern Great Basin and Mexico, respectively, and by Roukos et al. (2011a) in adjacent grasslands.

The optimum Mg requirements for sheep and beef cattle are $1.2 \mathrm{~g} / \mathrm{kg} \mathrm{DM}$ (NRC, 1985) and $1.0 \mathrm{~g} / \mathrm{kg} \mathrm{DM}$ (NRC, 1996) respectively. The results from this study suggest that in these phryganic ecosystemsonly during March, April and June the herbaceous vegetation is on the borderline to meet the sheep requirements in $\mathrm{Mg}$, while the $\mathrm{Mg}$ levels are insufficient to meet the beef cattle requirements throughout the grazing period. Thus, it can be assumed that there is an increased risk of $\mathrm{Mg}$ deficiency to occur in grazing livestock, a result also found by Roukos et al. (2011a). Conversely, Ramirez et al. (2009) reported that 13 grasses in Mexico had marginal sufficient levels of $\mathrm{Mg}$ to meet growing beef cattle requirements.

Minson (1990) stated that seasonal variation of $\mathrm{Mg}$ content within species are relative small and $\mathrm{Mg}$ concentration in herbage is affected by its botanical composition and climatic conditions (Mountousis et al. 2008; Suttle, 2010; Roukos et al., 2011a). Leguminous species have higher $\mathrm{Ca}$ and $\mathrm{Mg}$ content than grasses (Minson, 1990; Roukos et al., 2011a). Calcium 
and $\mathrm{Mg}$ content decreased from April to July and may reflect a lower legume contribution in vegetation composition (Suttle, 2010; Roukos et al., 2011a).

Magnesium is important for the metabolic stability of animals and must be evaluated in relation to $\mathrm{K}$ and $\mathrm{Ca}$ (NRC, 2005). A K/(Ca $+\mathrm{Mg}$ ) ratio in excess of 2.2 (milliequivalent cation basis) can accelerate grass tetany (Kemp and Hart, 1957; Grunes and Welch, 1989; Goff and Horst, 1997), especially for cows in early lactation (Jefferson $e t$ al., 2001).

The results of this study demonstrated that magnesium concentration was low in spring when potassium concentration was high. It seems that air temperature plays a role in the mineral content of herbage (Table 3). The rapid increase of air temperature during spring and the relative high $\mathrm{K}$ level in herbage compared to $\mathrm{Ca}$ and $\mathrm{Mg}$, increases the risk of grass tetany for grazing livestock. This suggestion concurs with Roukos et al. (2011a). Conclusively, the highest GTI value for the herbage $(\mathrm{GTI} \leq 1.39$ ) was much lower than the threshold value of 2.2 throughout the grazing period.

\section{Nutrient digestibility}

In vitro DM digestibility, IVNDFD and ME significantly varied $(\mathrm{P}<0.05)$ among harvest months (Table 4). All nutrient digestibility parameters had a progressive decrease during the grazing period which negatively correlated with air temperature (Table 2). It seems that CP content influenced positively nutrient digestibility parameters because when CP decreased, all parameters also decreased (Table 2). Conversely, cell wall contents negatively affected nutrient digestibility parameters. These results concur with the results of Ramirez et al. (2009), Mountousis et al. (2011) and Roukos et al. (2011a).

Moreover, a positive effect of mean monthly precipitation on nutrient digestibility parameters was revealed (Table 2). Precipitation influenced chemical composition and thus affected the nutrient digestibility parameters. Similar results also found by Ganskoop and Bohnert (2001), Mountousis et al. (2008) and Roukos et al. (2011a).

The IVDMD values in herbage samples ranged from 0.521 in July to 0.726 in March. These values concur with those reported by Perez-Corona et al. (1998), Vazquez de Aldana et al. (2000), Mountousis et al. (2008; 2011) and Roukos et al. (2011a).

Although IVNDFD is an empirical measurement of fiber fermentability by rumen microbes (Hall and Mertens, 2012), it might be a better indicator of DMI than NDF digestibility in vivo and, thus, is an important parameter of forage quality (Oba and Allen, 1999). The IVNDFD negatively correlated with cell wall content (Table 5) and decreased significantly throughout the grazing period (Table 4). In vitro NDF digestibility values ranged from 0.683 in March to 0.430 in July and are in agreement with those reported by Oba and Allen (1999), NRC (2001), Roukos et al. (2011). The low digestibility of NDF during the last two months of the grazing period, when lignin(sa) content was the highest, can have a dramatic impact on dietary energy content and DM intake (Oba and Allen, 1999).According to McDonald et al. (2002), lignin may bind cellulose and cell wall protein in strong chemical bonds, which makes these compounds undigestible.

The estimated ME values of the herbage ranged from 7.29 $\mathrm{MJ} / \mathrm{kg}$ to $10.95 \mathrm{MJ} / \mathrm{kg} \mathrm{DM}$ (Table 4). Similar resultshave been reported by Mountousis et al. (2011) and Roukos et al. (2011). The ME contents were sufficient to meet the maintenance requirement of $50 \mathrm{~kg}$ live weight sheep $(8.37 \mathrm{MJ} / \mathrm{kg} \mathrm{DM}$; NRC, 1985) and $200 \mathrm{~kg}$ live weight free ranging beef cattle (8.07 MJ/kg DM; NRC, 1996).

\section{Relationship between growing degree days and nutritional quality parameters}

Regression analyses quantified relationships between CP, NDF, lignin, IVDMD, IVNDFD and ME values of herbage and growing degree days (GDD) as independent variable (Fig. $2)$. The mathematical and statistical parameters of the regression analysis are given in Table 6.

All nutritional digestibility parameters were strongly associated with growing degree days. Moreover, the accuracy of the equation to predict IVDMD and CP content from growing degree days was very high (Adj. $\left.\mathrm{R}^{2}>0.90\right)$ and the accuracy of IVNDFD, ME, NDF and lignin contents was satisfactory (Adj. $\mathrm{R}^{2}>0.77$ ). According to the regression analysis, an increase of 100 growing degree days resulted in a

Table 3. Effect of time of harvest on mineral concentrations, ash content and grass tetany index (GT index) of herbaceous vegetation during the growing period

\begin{tabular}{|c|c|c|c|c|c|c|c|}
\hline Parameter & March & April & May & June & July & SEM & Sig. \\
\hline $\mathrm{Ca}(\mathrm{g} / \mathrm{kg} \mathrm{DM})$ & $3.88 \mathrm{a}$ & $4.19 \mathrm{a}$ & $3.72 \mathrm{a}$ & $3.43 \mathrm{bc}$ & $2.88 \mathrm{c}$ & 0.381 & ${ }^{*}$ \\
\hline $\mathrm{P}(\mathrm{g} / \mathrm{kg} \mathrm{DM})$ & $3.10 \mathrm{a}$ & $3.05 \mathrm{a}$ & $2.12 b$ & $2.39 \mathrm{~b}$ & $2.14 b$ & 0.232 & *** \\
\hline $\mathrm{K}(\mathrm{g} / \mathrm{kg} \mathrm{DM})$ & $14.3 \mathrm{a}$ & $12.8 \mathrm{ab}$ & $11.9 \mathrm{bc}$ & $11.2 \mathrm{c}$ & $9.3 \mathrm{~d}$ & 0.824 & *** \\
\hline $\operatorname{Mg}(\mathrm{g} / \mathrm{kg} \mathrm{DM})$ & $1.09 \mathrm{a}$ & $1.03 \mathrm{a}$ & $0.81 b$ & $1.02 \mathrm{a}$ & $0.83 b$ & 0.092 & $* *$ \\
\hline GT index $\left(\mathrm{mmol}_{\mathrm{c}} / \mathrm{kg} \mathrm{DM}\right)$ & $1.389 \mathrm{a}$ & $1.147 \mathrm{a}$ & $1.258 \mathrm{a}$ & $1.241 \mathrm{a}$ & $1.239 \mathrm{a}$ & 0.132 & NS \\
\hline $\operatorname{Ash}(\mathrm{g} / \mathrm{kg}$ DM) & $113.7 \mathrm{a}$ & $99.4 b$ & $82.5 \mathrm{c}$ & $68.3 \mathrm{~d}$ & $56.2 \mathrm{c}$ & 4.75 & *** \\
\hline
\end{tabular}

Within a row, means with different letters differ at $\mathrm{P}<0.05$.

$\mathrm{SEM}=$ standard error of the mean; Sig = significant leve

${ }^{*} \mathrm{P}<0.05 ;{ }^{* *} \mathrm{P}<0.01 ;{ }^{* *} \mathrm{P}<0.001 ; \mathrm{NS}=$ not significant

Table 4.Nutrient and energy digestibility of herbage vegetation in a prhyganic ecosystem during the grazing period

\begin{tabular}{|c|c|c|c|c|c|c|c|}
\hline Parameter & March & April & May & June & July & SEM & Sig. \\
\hline IVDMD & $0.726 a$ & $0.710 \mathrm{~b}$ & $0.671 \mathrm{c}$ & $0.626 \mathrm{~d}$ & $0.521 \mathrm{e}$ & 0.005 & $* * *$ \\
\hline IVNDFD & $0.683 a$ & $0.675 a$ & $0.665 a$ & $0.479 \mathrm{~b}$ & $0.430 \mathrm{c}$ & 0.009 & *** \\
\hline $\operatorname{ME}(\mathrm{MJ} / \mathrm{kg})$ & $10.95 a$ & $10.68 \mathrm{a}$ & $9.87 \mathrm{~b}$ & $8.27 \mathrm{c}$ & $7.29 \mathrm{~d}$ & 0.125 & *** \\
\hline $\mathrm{GE}(\mathrm{MJ} / \mathrm{Kg})$ & $18.60 \mathrm{~b}$ & $18.76 b c$ & $18.84 \mathrm{bc}$ & $18.89 \mathrm{~b}$ & $19.46 \mathrm{a}$ & 0.095 & *** \\
\hline
\end{tabular}

Within a row, means with different letters differ at $\mathrm{P}<0.05$

$\mathrm{M}=$ mean; $\mathrm{SEM}=$ standard error of the mean; $\mathrm{Sig}=$ significant level

${ }^{*} \mathrm{P}<0.05 ;{ }^{* *} \mathrm{P}<0.01 ;{ }^{* * *} \mathrm{P}<0.001 ; \mathrm{NS}=$ not significant 
154

Table 5.Correlation coefficients between nutritive quality parameters and chemical composition of herbage vegetation during the grazing period

\begin{tabular}{cccc}
\hline Parameter & IVDMD & NDF Digestibility & Metabolisable energy \\
CP & $0.863^{* \prime}$ & $0.867^{*}$ & $0.881^{*}$ \\
NDF & $-0.802^{*}$ & $-0.754^{*}$ & $-0.827^{*}$ \\
ADF & $-0.866^{*}$ & $-0.826^{*}$ & $-0.844^{*}$ \\
Lignin & $-0.833^{*}$ & $-0.888^{*}$ & $-0.836^{*}$ \\
\hline
\end{tabular}

${ }^{*} \mathrm{P}<0.05 ;{ }^{* *} \mathrm{P}<0.01$.

Table 6. Coefficients associated with growing degree days (GDD) for significant ${ }^{\mathrm{a}}$ variance regression analysis of crude protein $(\mathrm{CP}, \mathrm{g} / \mathrm{kg} \mathrm{DM})$, neutral detergent fiber (NDF, $\mathrm{g} / \mathrm{kg} \mathrm{DM})$, lignin ( $\mathrm{g} / \mathrm{kg} \mathrm{DM})$, in vitro dry matter digestibility (IVDMD), in vitro NDF digestibility (IVNDFD) and metabolizable energy (ME, MJ $/ \mathrm{kg} \mathrm{DM}$ ) as dependent variables during grazing period

\begin{tabular}{ccccc}
\hline & \multicolumn{2}{l}{ Regression equation } & Adjusted R $^{2}$ & SE \\
\hline $\mathrm{CP}$ & $=$ & $\begin{array}{c}0,000063(\mathrm{GDD})^{2}-0.205 \\
(\mathrm{GDD})+219\end{array}$ & 0.912 & 16.2 \\
$\mathrm{NDF}$ & $=$ & $0.197 \ln (\mathrm{GDD})+163$ & 0.849 & 10.3 \\
Lignin & $=$ & $\begin{array}{c}-0,000015(\mathrm{GDD})^{2}-0.052 \\
(\mathrm{GDD})+32\end{array}$ & 0.778 & 7.3 \\
$\mathrm{IVDMD}$ & $=$ & $-0,000189 \times(\mathrm{GDD})+0.738$ & 0.911 & 0.02 \\
$\mathrm{IVNDFD}$ & $=$ & $-0,00027 \times(\mathrm{GDD})+0.711$ & 0.825 & 0.04 \\
$\mathrm{ME}$ & $=$ & $0.0000015(\mathrm{GDD})^{2}-0,0053$ & 0.858 & 0.57 \\
\hline${ }^{2} \mathrm{C}$ & $(\mathrm{GDD})+11$ & &
\end{tabular}

${ }^{\mathrm{a}}$ Significant at the 0.05 probability level

decrease of 0.019 for IVDMD and 0.027 for IVNDFD. These results indicate that growing degree days is an important factor affecting the nutritive value of herbaceous vegetation in a phryganic ecosystem.

Studies have provided evidence that GDD is a useful indicator of forage maturity worldwide, since temperature is the most significant climatic variable affecting the rate of plant growth and development (Bootsma, 1984; Frank and Hofmann, 1989; Frank, 1996; Hendrickson et al., 1998; Nordheim-Viken et al., 2009; Peterson et al., 2010; White et al., 2012). Based on the results of this study, it is recommended that high nutritional quality herbage obtained during the period from March to May when GDD did not exceed the value of 700 . It seems that GDD values over 700 have a markedly negative impact on nutritional quality parameters of the herbaceous forage of a phryganic ecosystem.

\section{Conclusions}

This study provided evidence that harvest month significantly affected the nutritional quality of the herbaceous vegetation in phryganic ecosystems. During the grazing period, herbage biomass leaded to a decline in overall nutritional quality.

In the first part of grazing period, phryganic ecosystem herbage can be considered to be of high nutritional quality as it meets the livestock requirements. In this period, GDD value did not exceed the threshold of about 700 , over which the nutritional quality of herbage dramatically decreased. In the last part of the grazing period, a supplementation of protein, energy and minerals in ruminant diets is needed.

The prediction equations, based on the GDD, provided satisfactory accuracy of IVDMD, IVNDFD and CP, NDF and ME contents of herbage. These equations can be utilized in similar phryganic ecosystems in the Mediterranean region.
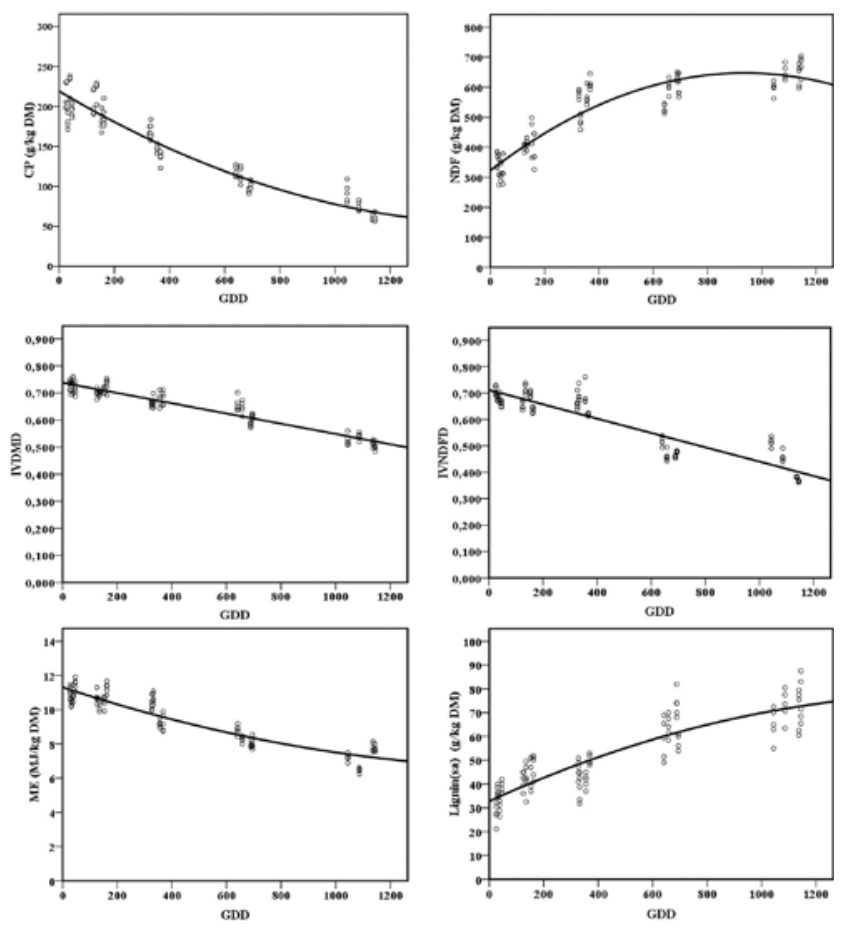

Fig. 2. Relationships between growing degree days (GDD) and $\mathrm{CP}, \mathrm{NDF}$, lignin and ME content, IVDMD and IVNDFD. The symbol $(0)$ indicates the observed values

Nevertheless, in order to improve the accuracy of the prediction equations based on the GDD, which is a parameter relatively independent of the climatic variability, further research is required.

\section{References}

A.O.A.C. (2000). Official Methods of Analysis, 17th ed. Gaithersburg, MD, USA.

Acar Z, Kumbasar F, Ayan I, Can M, Tuzen E, Zeybek S, Kaymak G (2016). Effects of plant development phases on some morphological, agronomical and chemical traits of Bituminaria bituminosa genotypes. Options Mediterraneennes Series A:169-172.

Allen MS (1996). Physical constraints on voluntary intake of forages by ruminants.Journal of Animal Science 74:3063-3075.

Ayan I, Acar Z, Mut H, Basaran U, Asci O (2006). Morphological, Chemical and Nutritional Properties of Forage Plants in a Natural Rangeland in Turkey. Bangladesh Journal of Botany 35(2):133-142.

Bergmeier E (1997). Combined effects of fire and grazing on phryganic vegetation - a case study in SW Crete (Greece). Ecologia Mediterranea 23:1-10.

Bergmeier E, Matthäs U (1996). Quantitative studies of phenology and early effects of non-grazing in Cretan phryganic vegetation. Journal of Vegetation Science 7:229-236. 
Bertrand A, Tremblay GF, Pelletier S, Castonguay Y, Bélanger G (2008). Yield and nutritive value of timothy as affected by temperature, photoperiod and time of harvest. Grass and Forage Science 63:421-432.

Bootsma A (1984).Forage crop maturity zonation in the Atlantic region using growing degree-days. Canadian Journal of Plant Science 64:329338.

Bovolenta S, Spanghero M, Dovier S, Orlandi D, Clementel F (2008). Chemical composition and net energy content of alpine pasture species during the grazing period. Animal Feed Science and Technology 146:178-191.

Broderick GA (2003). Effects of varying dietary protein and energy levels on the production of lactating dairy cows. Journal of Dairy Science 86:1370-1381.

Caple IW, West DM (1992). Ruminant hypomagnesaemic tetanies. In:Howard JL (Ed). Current Veterinary Therapy 3:Food Animal Practice. Philadelphia: Saunders pp 318-321.

Cherubini P1, Gartner BL, Tognetti R, Bräker OU, Schoch W, Innes JL (2003). Identification, measurement and interpretation of tree rings in woody species from Mediterranean climates. Biological Reviews 78(1):119-148.

Coleman SW, Moore JE (2003). Feed quality and animal performance. Field Crops Research 84:17-29.

Debazac EP, Mavrommatis G (1969). Note sur les formations forestieres "a feuilles persistantes" en Greece. Strengthening of the Forest Research Institute, Athens $23 \mathrm{p}$.

Frank AB (1996). Evaluating Grass Development for Grazing Management. Rangelands 18(3)106-109.

Frank AB, Hofmann L (1989). Relationship among grazing management, growing degree-days, and morphological development for native grasses on the northern Great Plains. Journal of Range Management 42:199202.

Frank KW, Gaussoin RE, Riordan TP, Miltner ED (1998). Date of planting effects on seeded turf-type buffalograss. Crop Science 38:12101213.

Ganskoop D, Bohnert R (2001). Nutritional dynamics of 7 northern Great Basin grasses. Journal of Range Management 54:640-647.

Geist HJ, Lambin EF (2004). Dynamic causal patterns of desertification. Bioscience $54(9)$ 817-829.

Goff JP, Horst RL (1997). Physiological changes at parturition and their relationship to metabolic disorders. Journal of Dairy Science 80:12601268.

Greuter W, Burdet H, Long G (1986). Med-Checklist, Vol 3. Conservatoire et Jardin Botaniques, Ville de Geneve, 310.

Grunes DL, Welch RM (1989). Plant contents of magnesium, calcium and potassium in relation to ruminant nutrition. Journal of Animal Science 67(12):3485-3494

Hall MB, Mertens DR (2008). In vitro fermentation vessel type and method alter fiber digestibility estimates. Journal of Dairy Science 91:301-307.

Hall MB, Mertens DR (2012). A ring test of in vitro neutral detergent fiber digestibility: analytical variability and sample ranking. Journal of Dairy Science 95(4):1992-2003.

Hatzianastassiou N, Katsoulis B, Pnevmatikos J, Antakis V (2008). Spatial and Temporal Variation of Precipitation in Greece and Surrounding
Regions Based on Global Precipitation Climatology Project Data. Journal ofClimate21(6):1349-1370.

Hendrickson JR, Moser LE, Moore KJ, Waller SS (1998). Morphological development of 2 warm-season grasses in the NebraskaSandhills Journal of Range Management 51:456-462.

Holechek JL, Pieper RD, Herbel CH (2010). Range Management Principles and Practices. Sixth Edition. Prentice-Hall Inc. Upper Saddle River,NJ.

Hellenic National Meteorological Service (HNMS) (2009). Climatology Arta, Athens www.hnms.gr/hnms/english/climatology.

Hristov AN, Etter RP, Ropp JK, Grandeen KL (2004). Effect of dietary crude protein level and degradability on ruminal fermentation and nitrogen utilization in lactating dairy cows. Journal of Animal Science 82:3219-3229.

Jefferson PG, Mayland HF, Asay KH, Berdahl JD (2001). Variation in mineral concentration and grass tetany potential among Russian wildrye accessions. CropScience 41:543-548.

Kandrelis SS (1995). Effect of clipping and burning on Pblomis fruticosa L. reproduction and their implications on the productivity of phlometum ecosystem. PhD Thesis. Thessaloniki, Greece.

Kandrelis SS (2000). Range management in Epirus: Present situation and problems. In: Papachristou TH, Gini-Papanastsi O (Eds). Range Science at the threshold of the 21st century. Proceedings of the 2nd Panhellenic Rangeland Congress pp 23-29.

Kemp A, Hart JL (1957). Grass tetany in grazing milking cows. Netherlands Journal of Agricultural Science 4:5-17.

Kyparissis A, Grammatikopoulos G, Manetas Y (1997). Leaf demography and photosynthesis as affected by the environment in the drought semideciduous Mediterranean shrub Phlomis fruticosa L. Acta Oecologica 18(5):543-555.

Kypasissis A, Manetas Y (1993). Seasonal leaf dimorphism in a semideciduous Mediterranean shrub: Ecophysiological comparisons between winter and summer leaves. Acta Oecologica 14:23-32.

McDonald P, Edwards RA, Greenhalgh JED, Morgan CA (2002). Animal nutrition, 6th Ed. Pearson Education Limite Ashford Colour Press Ltd Gosport.

Merkel RC, Pond KR, Burns JC, Fisher DS (1999). Intake, digestibility and nitrogen utilization of three tropical tree legumes: II. As protein supplement. Animal Feed Science and Technology 82:107-120.

Merten DR (1994). Regulation of forage intake. In: Fahey GC (Ed). Forage Quality, Evaluation and Utilization. American Society of Agronomy, Madison, WI, USA pp 450-493.

Minson DJ (1990). Forage in Ruminant Nutrition. Academic Press, New York.

Montalvo J, Casado MA, Levassor C, Pinedo FD (1991). Adaptation of ecological systems: compositional patterns of species and morphological and functional traits. Journal of Vegetation Science 2:655-666.

Mountousis I, Papanikolaou K, Chatzitheodoridis F, Roukos C and Papazafeiriou A (2006). Monthly chemical composition variations in grazable material of semi-arid rangelands in north-western Greece.Livestock Research for Rural Development Vol 18 Art 155. Retrieved November 14, 2016, from http://www.lrrd.org/ $\operatorname{lrrd} 18 / 11 /$ moun18155.htm 
156

Mountousis I, Papanikolaou K, Stanogias G, Chatzitheodoridis F, Roukos C (2008). Seasonal variation of chemical composition and dry matter digestibility of rangelands in NW Greece. Journal of Central European Agriculture 9(3):547-556.

Mountousis I, Dotas V, Stanogias G, Papanikolaou K, Roukos C, Liamadis D (2011). Altitudinal and seasonal variation in herbage composition and energy and protein content of grasslands on Mt Varnoudas, NW Greece. Animal Feed Science and Technology 164(3):174-183.

National Research Council (1985). Nutrients Requirements of Sheep, 6th revised ed. National Academy Press, Washington, DC, USA

National Research Council (1996). Nutrient Requirements of Beef Cattle, 7th revised ed. National Academy Press, Washington, DC, USA.

National Research Council (2005). Mineral Tolerance of Animals, 2nd revised ed. National Academy Press, Washington, DC, USA

National Research Council (2001). Nutrient Requirements of Dairy Cattle. 7th reved. Natl AcadSci, Washington, DC.

Nordheim-Viken H, Volden H, Jørgensen M (2009). Effects of maturity stage, temperature and photoperiod on growth and nutritive value of timothy (Phleum pratense L.). Animal Feed Science and technology 152:204218.

ObaM, Allen MS (1999). Evaluation of the importance of the digestibility of neutral detergent fiber from forage: effects on dry matter intake and milk yield of dairy cows. Journal of Dairy Science 82:589-596.

Papanastasis VP, Kyriakakis S, Kazakis G (2002). Plant diversity in relation to overgrazing and burning in mountain Mediterranean ecosystems. Journal of Mediterranean Ecology3(2-3):53-63.

Pelletier ES, Belanger G, Tremblay GF, Brecard A, Allard G (2006). Dietary cation-anion difference (DCAD) of timothy as affected by development stage and $\mathrm{N}$ and $\mathrm{P}$ fertilization. Agronomy Journal 98:774780.

Perez-Corona ME, Vazquez de Aldana BR, Garcia-Criado B, GarciaCiudad A (1998). Variations in nutritional quality and biomass production of semiarid grasslands. Journal of Range Management 51:570-576.

Peterson KW, Shearman RC, Gaussoin RE, Horst GL, Schacht WH (2010). Growing Degree-day Influence on Sprigged Establishment of Two Buffalograss Cultivars. HortScience 45(2):293-298.

Pruess KP (1983). Day-degree methods for pest management. Environmental Entomology 12:613-619.

Pugh DG, Baird AN (2012). Sheep and goat medicine (2nd Ed). Elsevier Saunders.

Ramirez RG, Haenlein GFW, Garcia-Castill CG, Nuńez-Gonzalez MA (2004). Protein, lignin and mineral contents and in situ dry matter digestibility of native Mexican grasses consumed by range goats. Small Ruminant Research 52:261-269.
Ramirez RG, Gonzalez-Rodriguez H, Morales-Rodriguez R, Cerrillo-Soto A, Juarez-Reyes A, Garcia-Dessommes GJ, Guerrero-Cervantes M (2009). Chemical composition and dry matter digestion of some native and cultivated grasses in Mexico. Czech Journal of Animal Science 54(4):150-162.

Roukos C, Papanikolaou K, Nikolaou E, Chatzitheodoridis F, Mountousis I (2008). Effects of fertilization and clipping of Phlomis fruticosa $\mathrm{L}$. on a phryganic ecosystem: the case of Thesprotia, Northwest Greece. American Journal of Environmental Sciences 4(6):551-557.

Roukos C, Papanikolaou K, Kandrelis S, Mygdalia A, Koutsoukis Ch, Glavas E (2010). Production and nutritional quality of low elevation zone grasslands and kermes oak shrublands (Quercus coccifera L.) in the south-east Mediterranean Basin. American Journal of Animal and VeterinarySciences 5(1):52-59.

Roukos C, Papanikolaou K, Karalazos A, Chatzipanagiotou A, Mountousis I, Mygdalia A (2011a). Changes in nutritional quality of herbage botanical components on a mountain side grassland in north-west Greece. Animal Feed Science and Technology 169:2434.

Roukos C, Papanikolaou K, Mountousis I, Kandrelis S, Chatzitheodoridis F (2011b). Soil properties variations in relation to plant community and altitudinal zone in the rangelands of Epirus, Greece. Bulgarian Journal of Agricultural Science: 17(6):806-815.

SCA (1990). Feeding Standards for Australian Livestock. Ruminants. Standing Committee on Agriculture and CSIRO, Melbourne.

SuttleNF (2010). Mineral nutrition of livestock. CAB International.

Thornton PK (2010). Livestock production: recent trends, future prospects. Philosophical Transactions of the Royal Society B 365:2853-2867.

Unruh JB, Gaussoin RE, Wiest SC (1996). Basal growth temperatures and growth rate constants of warm-season turfgrass species. Crop Science 36:997-999.

Vazquez-de-Aldana BR, García-Ciudad A, Pérez-Corona ME, GarcíaCriado B (2000). Nutritional quality of semi-arid grassland in western Spain over a 10-year period: changes in chemical composition of grasses, legumes and forbs. Grass and Forage Science 55:209-220.

Vogel KP, Pedersen JF, Masterson SD, Toy JJ (1999). Evaluation of a filter bag system for NDF.ADF, and IVDMD forage analysis. Crop Science 39:276-279.

Wang H, Inukai Y, Yamauchi A (2006). Root development and nutrient uptake. Critical Reviews in Plant Science 25:279-301.

White SN, Boyd NS, Van Acker RC (2012). Growing Degree-day Models for Predicting Lowbush Blueberry (Vaccinium angustifolium Ait.) Ramet Emergence, Tip Dieback, and Flowering in Nova Scotia, Canada. HortScience 47(8):10141021. 